\title{
PENERAPAN ALGORITMA ANT COLONY OPTIMIZATION MENENTUKAN NILAI OPTIMAL DALAM MEMILIH OBJEK WISATA BERBASIS ANDROID
}

\author{
Euis Nurlaelasari \\ Program Teknik Informatika \\ STMIK Kharisma Karawang \\ Email: euisnurlaela333@gmail.com \\ Supriyadi \\ STMIK Kharisma Karawang \\ Email: supriyadistmikkharisma@yahoo.com \\ U. Tresna Lenggana \\ STMIK Kharisma Karawang \\ Email: trena.mobile.pro@gmail.com
}

\begin{abstract}
ABSTRAK
Pencarian nilai yang optimal adalah permasalahan yang dapat dijumpai pada kehidupan sehari-hari. yaitu seperti, menentukan rute terpendek, menentukan jumlah optimal untuk persediaan hasil produksi dan lain-lain. Pencarian nilai optimal dapat digunakan untuk memperoleh nilai tertinggi dan terendah dari suatu permasalahan. Salah satu permasalahan yang populer dan dapat dipecahkan dengan algoritme optimasi adalah Traveling Salesman Problem (TSP) untuk menentukan rute terdekat dengan menggunakan algoritme Ant Colony Optimization. Namun pada kenyataannya, jarak bukanlah satusatunya tolak ukur yang dapat diperhitungkan saat melakukan perjalanan. Oleh karena itu, penelitian ini bertujuan untuk melengkapi kekurangan pada penelitian sebelumnya dengan menambahkan variabel lain selain jarak. Algoritma Ant Colony Optimization digunakan untuk menentukan objek wisata dengan menghitung variabel biaya pada sebuah jarak. Sehingga dapat menghasilkan sebuah biaya transportasi terendah. Hasil dari penelitian ini berupa rancangan sistem dengan menggunakan UML (Use case, Class, Sequence, Activity Diagram) dan rancangan aplikasi pemilihan objek Wisata Karawang berbasis android dengan menerapkan Algoritme Ant Colony Optimization. Metode pengembangan sistem yang digunakan adalah System Development Life Cycle (SDLC) Waterfall serta rancangan sistem berbasis Object Oriented.
\end{abstract}

Kata kunci: ant colony optimization, biaya, objek wisata, traveling salesman problem.

\begin{abstract}
The search for an optimal value is a problem that can be found in everyday life such as, determining the shortest route, determining the optimal amount of inventory of production and others. The search for the optimal value can be used to obtain the highest and lowest value of a problem one of the most popular and solvable problems with the optimization algorithm is the Traveling Salesman Problem (TSP) to determine the nearest route by using ant colony optimization algorithm. But in reality, distance is not the only measurable benchmark when traveling. Therefore, this study aims to supplement the deficiencies in previous research by adding other variables besides the distance Algorithm Ant Colony Optimization is used to determine the object of tourism by calculating the variable cost at a distance. So that can produce a transportation cost lowest The result of this research is in the form of system design using UML (Use case, Class, Sequence, Activity Diagram) and the design of Karawang-based Tourism object selection app by applying Ant Colony Optimization Algorithm. System development method used is System Development Life Cycle (SDLC) Waterfall and Object Oriented based system design.
\end{abstract}

Keywords: ant colony optimization, cost, trourist attraction, traveling salesman problem.

\section{PENDAHULUAN}

Pencarian nilai yang optimal adalah permasalahan yang dapat dijumpai pada kehidupan sehari-hari. Permasalahan tersebut seperti menentukan rute terpendek [1], menentukan jumlah optimal untuk persediaan hasil produksi [2], penentuan nilai risiko kredit tertinggi pada bank [3], dan nilai optimum 
profit, weight atau density pada knapsack problem [4]. Pencarian nilai optimal dapat digunakan untuk memperoleh nilai tertinggi dan terendah dari suatu permasalahan. Sebagai contoh, pada kasus pencarian benefit maka yang akan diambil adalah nilai tertinggi, sedangkan untuk permasalahan risiko kredit dan pencarian rute terdekat maka yang akan diambil adalah nilai terkecil.

Pencarian rute terdekat sangat populer dan bisa dijumpai pada Traveling Salesman Problem (TSP) [5]. Pada TSP, variabel yang dihitung adalah jarak antara titik atau objek yang akan dikunjungi sebagai bobot dari graph. Pada implementasinya pencarian rute terpendek bisa menggunakan algoritme optimasi seperti algoritme genetika [6], algoritme Tabu Search [7], algoritme djikstra [8] atau algoritme Ant Colony Optimization [1]. Dalam kenyataannya ketika melakukan sebuah perjalanan, jarak bukanlah satusatunya tolak ukur yang dapat dihitung. Alat transportasi yang digunakan juga dapat diperhatikan yang nantinya akan menjadi bahan perhitungan dalam hal penggunaan biaya perjalanan. Namun belum ada sistem penunjang keputusan untuk menentukan nilai optimum berdasarkan variabel jarak dan biaya.

Oleh karena itu pada penelitian ini diharapkan memberikan solusi untuk penentuan nilai optimal dengan jarak dan biaya sebagai variabel yang dihitung menggunakan algoritme Ant Colony Optimization (ACO).

Pembangunan sistem akan menggunakan metode System Development Life Cycle (SDLC) Waterfall [9]. Berdasarkan pertimbangan diatas, maka penelitian ini bertujuan untuk melengkapi kekurangan pada penelitian sebelumnya dengan menambahkan variabel biaya pada jarak menggunakan Algoritme Ant Colony Optimization untuk menentukan nilai optimal dalam memilih Objek Wisata di Karawang.

\section{METODOLOGI PENELITIAN}

\subsection{Metodologi System Development Life Cycle (SDLC) Waterfall}

Metode ini merupakan metode yang sering digunakan oleh penganalisis sistem pada umumnya. Metode waterfall adalah suatu metodologi pengembangan perangkat lunak yang mengusulkan pendekatan kepada perangkat lunak semantik dan sekuensial yang mulai pada Project Planning phase, Analysis phase, Design phase, Implementation phase, suport phase [9]. Namun penulis membatasi proses hanya sampai implementation phase. seperti pada gambar 1.

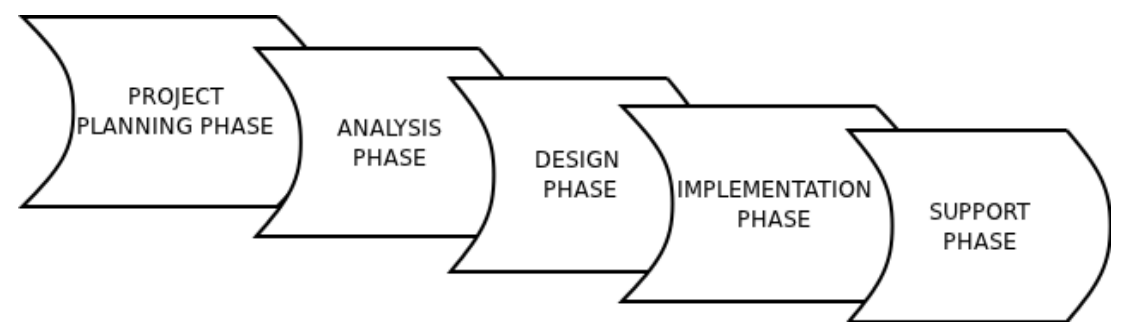

\section{Gambar 1. Tahapan Metode Waterfall}

\subsubsection{Project Planning Phase}

Tahap perencanaan adalah tahap awal penelitian untuk memahami algoritme Ant Colony Optimization yang diterapkan untuk menghitung biaya transportasi terendah. Penjelasan aktivitas yang yang dilakukan pada tahap ini dapat dilihat pada Tabel 1. 
Tabel 1. Rincian project planning phase

\begin{tabular}{lll}
\hline No & Tahapan & Deskripsi \\
\hline 1 & Identifikasi Masalah & Belum adanya pencarian optimasi yang menghitung jarak dan biaya \\
2 & Pengumpulan Data & $\begin{array}{l}\text { Melakukan studi literstur melalui ebook dan buku mengenai algoritme } \\
\text { ACO dan data mengenai objek wisata dan tarif angkutan umum } \\
\text { Kabupaten Karawang }\end{array}$ \\
& Menganalisis Teori & $\begin{array}{l}\text { Melakukan analisis pada algoritme ACO dan metode pengembangan } \\
\text { SDLC Waterfall }\end{array}$ \\
4 & Pembuatan Jadwal & $\begin{array}{l}\text { Membuat rencana pengembangan dan target pembuatan aplikasi } \\
\text { Menentukan varibel yang akan dihitung yaitu jarak dan biaya }\end{array}$ \\
& Mencari Solusi & $\begin{array}{l}\text { menggunakan perhitungan algoritme ACO, dengan mencari nilai } \\
\text { optimal terendah }\end{array}$ \\
& & Menentukan tools yang dibutuhkan untuk pembangunan sistem. \\
& Kengidentifikasi &
\end{tabular}

\subsubsection{Analysis Phase}

a. 2.1.2.1 Analisis Teori

Pada tahap ini dilakukan analisis terhadap algoritme ant colony optimization. Ada beberapa varian ACO yang berkembang dari tahun 1991 hingga 2001, yakni Ant System (AS). Elitist AS, Ant-Q, Ant Colony System, MAX-MIN AS, Rank-based AS, ANTS, BWAS dan Hyper-cube AS [10]. Namun pada penelitian ini akan menggunakan Ant System. Berikut adalah tahapan perhitungan dari AS, dapat dilihat pada Tabel 2:

Tabel 2. Analisis Teori

\begin{tabular}{ll}
\hline No & Tahapan \\
\hline 1 & Identifikasi $\boldsymbol{d}_{\text {if }}$ \\
2 & $\begin{array}{l}\text { Inisialisasi Parameter } \\
\text { awal bagi pheromone } \\
\text { pada waktu ke- } t\end{array}$
\end{tabular}

3 Menentukan Jumlah Semut

Deskripsi

$\boldsymbol{d}_{\text {if }}$ adalah jarak dari node $i$ ke node $j$. dalam penelitian ini $\boldsymbol{d}_{i j}$ digantikan dengan $\boldsymbol{c}_{i \mathrm{if}}$ yaitu biaya dari node $i$ ke $j$

$t=0 \quad\{t$ adalah penghitung waktu $\}$

$\mathrm{NC}=0 \quad\{\mathrm{NC}$ adalah penghitung cycle $\}$

Untuk setiap busur $(i, j)$, tentukan nilai awal untuk intensitas jejak pheromone, $\boldsymbol{\tau}_{i j}(\boldsymbol{t})=\mathbf{0}$.

Letakkan $m$ semut pada $n$ nodes (kota). $k=$ semut ke- $k, m=$ jumlah semut. for $k=1$ to $m$ do

Letakkan kota awal untuk semut ke- $k$ di dalam $t a b u_{k}(s)$ end

$4 \quad$ Membuat tabulist

Setiap semut membuat tabulist masing-masing. for $k=1$ to $m$ do pilih kota $j$ sebagai kota berikutnya yang akan dikunjungi, dengan probabilitas

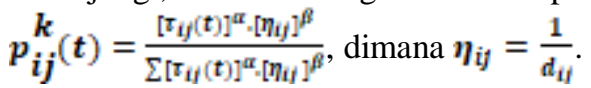
\{pada waktu $t$, semut ke- $k$ berada pada kota $\left.i=t a b u_{k}\right\}$

Pindahkan semut ke- $k$ ke kota $j$

Masukkan kota $j$ ke $\operatorname{tabu}_{k}(s)$

end

5 Hitung probabilitas dan Menghitung probabilitas pada tabulist dengan pheromone pada tabulist

$L_{k}=\sum P_{i j}^{k}(t)$ dan menghitung pheromone dengan $\Delta \tau_{i j}^{k}=\frac{Q}{L_{k}}$.

Kemudian tentukan tabulist dengan nilai terbaik yaitu tabulist 
6 Lakukan Iterasi

$7 \quad$ Update pheromone

$8 \quad$ Cetak hasil dengan nilai probabilitas tertinggi.

Jika iterasi dilakukan maka lakukan tahap 7 kemudian lakukan perhitungan kembali ke tahap 1 dengan nilai pheromone yang telah diperbaharui. Jika iterasi tidak dilakukan maka lakukan tahap 8 .

Tahap menambahkan pheromone untuk perhitungan pada iterasi selanjutnya, dengan $\tau_{i j}(t+n)=\rho \cdot \tau_{i j}(t)+\Delta \tau_{i j}$.

Menampilkan hasil terbaik berdasarkan hasil tahap ke-5.

b. Analisis Sistem

Pada tahap ini dilakukan analisis sistem pada pembuatan aplikasi dengan menggunakan Object Oriented Analysis (OOA). Hasil dari tahapan ini adalah tujuan pembangunan sistem terhadap masalah serta manfaat yang akan diperoleh. Tahapan dari analisis tersebut yaitu:

1. System activities (use case diagram, deskripsi use case, aktor dan skenario)

2. Class Diagram

3. Object interaction (sequence diagram)

4. Object behaviour (activity diagram)

\subsubsection{Design Phase}

Pada tahapan ini akan membuat desain sistem berdasarkan kebutuhan pengguna dan sistem, yang telah diidentifikasi dan ditentukan solusinya pada tahapan analisis sebelumnya. Desain yang yang akan dirancang adalah berdasarkan Object Oriented Design (OOD) yang terdiri dari:

a. Desain Proses

b. Desain Antarmuka

\subsubsection{Implementation phase}

Tahap implementasi adalah tahap penerapan desain yang telah dirancang kemudian diaplikasikan dalam bentuk program aplikasi. Kode program disusun menuruti disain program yang telah dirancang sebelumnya. Penulisan kode program tersebut dilakukan dengan teknik Object Orientied Programming (OOP). Dimana sebuah sistem didefinisikan menggunakan set yang lebih kecil dari objek yang saling terkait.

Tahap implementasi dilakukan dengan beberpa tahapan, yaitu:

a. Instalasi Sistem

Menjelaskan tahapan-tahapan dilakukannya proses instalasi aplikasi android.

b. Pelatihan Prosedural

Pelatihan tatacara penggunaan aplikasi yang telah diinstal didalam komputer.

c. Pengujian Terhadap Sistem

Pengujian sistem dilakukan dengan pengujian black box dan white box. Pengujian white box dilakukan pada fungsi utama aplikasi android pemilihan objek wisata. Sedangkan pengujian black box dilakukan untuk menguji fungsi-fungsi didalam program sehingga sesuai dan dapat berjalan dengan benar.

\section{HASIL DAN PEMBAHASAN}

Berdasarkan pada metode yang telah dipilih, pada tahap ini merupakan pembahasan dari fase-fase SDLC Waterfall. Tahap pertama Project Planning Phase berisi hasil dari aktivitas mengidentifikasi masalah, mengumpulkan data, menganalisis data dan mengidentifikasi kebutuhan penelitian. Tahap Analysis Phase yaitu berisi pembahasan mengenai analisis teori Algoritme ACO dan analisis sistem untuk kebutuhan sistem. Tahap selanjutnya adalah membuat desain sistem menggunakan Activity Diagram dan desain antarmuka sistem. Tahap terakhir adalah implementasi, yaitu dengan membuat aplikasi Pemilihan Objek Wisata berbasis Android. 


\subsection{Project Planning Phase}

Pada tahap ini dihasilkan rincian dari setiap aktivitas yang dilakukan, mulai dari identifikasi masalah yaitu bagaimana membuat aplikasi pemilihan objek wisata berdasarkan biaya transportasi terendah, pengumpulan data yang didapatkan dari Dinas Perhubungan Karawang, menganalisis data biaya angkutan umum dan objek wisata Kabupaten Karawang serta menerapkan data tersebut pada perhitungan algoritme ACO, melakukan perhitungan pemilihan objek wisata dengan biaya terendah menggunakan algoritme ACO dan mendefinisikan kebutuhan penelitian yaitu laptop, Smartphone, Linux Ubuntu 12.04 32-bit, LibreOffice Writer, LibreOffice Impress, Eclipse 2.1.1, Android SDK 23. Gaphor, Dia Diagram.

\subsection{Analysis Phase}

Di dalam tahapan analisis ini meliputi analisis teori algoritme ACO, yaitu berupa data biaya transportasi objek pariwisata di Karawang dan hasil perhitungan ACO terhadap variabel biaya pada rute pariwisata di Karawang. Serta analisis sistem untuk kebutuhan pembangunan aplikasi.

\subsubsection{Analisis Teori}

Pada tahapan ini akan menjelaskan tentang menentukan suatu tour terbaik berdasakan biaya transportasi terendah pada objek wisata di Karawang, yang akan dipecahkan dengan menggunakan algoritme ACO. Perhitungan algoritme ACO dapat dibagi dalam beberapa tahapan seperti berikut:

a. Identifikasi $\boldsymbol{d}_{\text {if }}$ $\boldsymbol{D}_{i \mathrm{i}}$ adalah jarak dari node $i$ ke node $j$. pada penelitian ini, variabeld $\boldsymbol{d}_{i f}$ diganti dengan $\boldsymbol{c}_{i \mathrm{ij}} \mathrm{yaitu}$ biaya dari node $i$ ke node $j$. Berikut data $c_{i j}$ dalam bentuk matriks dapat dilihat pada Tabel 3 .

Tabel 3. Matriks biaya antar node objek wisata

\begin{tabular}{|c|c|c|c|c|c|c|c|c|c|c|c|c|c|c|}
\hline \multicolumn{15}{|c|}{ Node Objek Wisata } \\
\hline & 1 & 2 & 3 & 4 & 5 & 6 & 7 & 8 & 9 & 10 & 11 & 12 & 13 & 14 \\
\hline 1 & 0 & 9500 & 6000 & 11500 & 11500 & 18500 & 7000 & 7000 & 7000 & 8725 & 8725 & 8725 & 24950 & 24950 \\
\hline 2 & 9500 & 0 & 3500 & 16000 & 10000 & 10000 & 16500 & 16500 & 16500 & 16500 & 16500 & 18225 & 34450 & 34450 \\
\hline 3 & 6000 & 3500 & 0 & 10000 & 10000 & 16000 & 13000 & 13000 & 13000 & 14725 & 14725 & 14725 & 30950 & 30950 \\
\hline 4 & 11500 & 16000 & 10000 & 0 & 19000 & 19000 & 25500 & 25500 & 25500 & 27225 & 27225 & 27225 & 32450 & 32450 \\
\hline 5 & 11500 & 10000 & 10000 & 19000 & 0 & 19000 & 19500 & 19500 & 19500 & 19500 & 19500 & 21225 & 37450 & 37450 \\
\hline 6 & 18500 & 10000 & 16000 & 19000 & 19000 & 0 & 25500 & 25500 & 25500 & 27225 & 27225 & 27225 & 32450 & 32450 \\
\hline 7 & 7000 & 16500 & 13000 & 25500 & 19500 & 25500 & 0 & 7000 & 7000 & 8725 & 8725 & 8725 & 24950 & 24950 \\
\hline 8 & 7000 & 16500 & 13000 & 25500 & 19500 & 25500 & 7000 & 0 & 3500 & 5225 & 5225 & 8725 & 21450 & 21450 \\
\hline 9 & 7000 & 16500 & 13000 & 25500 & 19500 & 25500 & 7000 & 3500 & 0 & 3500 & 3500 & 8725 & 19725 & 19725 \\
\hline 10 & 8725 & 16500 & 14725 & 27225 & 19500 & 27225 & 8725 & 5225 & 3500 & 0 & 3500 & 10450 & 19725 & 19725 \\
\hline 11 & 8725 & 16500 & 14725 & 27225 & 19500 & 27225 & 8725 & 5225 & 3500 & 3500 & 0 & 10450 & 19725 & 19725 \\
\hline 12 & 8725 & 18225 & 14725 & 27225 & 21225 & 27225 & 8725 & 8725 & 8725 & 10450 & 10450 & 0 & 10450 & 10450 \\
\hline 13 & 24950 & 34450 & 30950 & 32450 & 37450 & 32450 & 24950 & 21450 & 19725 & 19725 & 19725 & 10450 & 0 & 21450 \\
\hline 14 & 24950 & 34450 & 30950 & 32450 & 37450 & 32450 & 24950 & 21450 & 19275 & 19725 & 19725 & 10450 & 21450 & 0 \\
\hline
\end{tabular}

Keterangan:

Node baris maupun node kolom dapat menjadi node $i$ atau $j$ 
Keterangan node objek wisata:

1. Vihara Shia Jin Kupoh

2. Tugu Perjuangan

3. Rumah Djiaw Kie Siong

4. Pantai Pelangi

5. Pantai Samudra Baru

6. Pantai Tanjung Pakis

7. Kampung Budaya

8. Monumen Surotokunto

9. Bendungan Walahar

10. Situs Cikubang

11. Kebon Kembang \& Situ Kamojing

12. Makam Syekh Quro \& Makam Syekh Bentong

13. Pasir Putih

14. Makam Mantan Bupati Karawang

b. Inisialisasi Parameter Awal bagi Pheromone pada Waktu Ke- $t$

Parameter $\alpha, \beta$, $\rho$ mengikuti nilai yang telah ditetapkan sebelumnya, sedangkan pheromone yang dilambangkan dengan simbol ( $\left.\boldsymbol{\tau}_{\boldsymbol{i f f}}\right)$ pada waktu ke- $t$, mula-mula diberi nilai awal 1 yang nantinya akan mengalami perubahan dengan update pheromone pada tahap ke-7. Berikut adalah nilai parameter:

$$
\begin{aligned}
& \tau_{i j}(t)=1 \\
& \alpha=1 \\
& \beta=2 \\
& \rho=0.5
\end{aligned}
$$

Parameter $\boldsymbol{\alpha}_{s} \boldsymbol{\beta}$ dan $\boldsymbol{\tau}_{i j}$ digunakan pada tahap 4, sedangkan $\boldsymbol{\rho}$ digunakan pada tahap ke-7.

c. Menentukan Jumlah Semut

Pada tahap ini adalah penentuan jumlah semut yang akan diletakan pada tiap node untuk melakukan tour. Jumlah semut disimbolkan dengan $(m)$ dan diberi nilai 14 sesuai dengan jumlah node objek wisata.

d. Membuat Tabulist

Semut yang telah diletakkan pada masing-masing node mulai melakukan tour dan menghasilkan sebuah path atau rute. Jumlah tabulist akan sebanding dengan jumlah semut, maka tabulist akan berjumlah 14.

Langkah-langkah menentukan tabulist:

1. Letakan semut pada node $i$

Misalkan pada tabulist ke-1 oleh semut ke-1. Mula-mula semut diletakan pada node ke-1, maka node $i$ sama dengan node 1 . Selanjutnya semut akan menuju node $j$.

2. Menentukan node $j$

Node $j$ adalah node antara node 1 sampai dengan 14 pada node objek wisata. Cara untuk menentukannya ialah berdasarkan nilai probabilitas terbesar, untuk mengetahuinya maka digunakan rumus:

$$
\begin{aligned}
& \text { invers biaya }=\eta_{i j}=\frac{1}{c_{i f}}, \text { dan } \\
& \text { probabilitas }=p_{i j}^{k_{j}}(\boldsymbol{t})=\frac{\left[\tau_{i j}(t)\right]^{\alpha} \cdot\left[\eta_{i j}\right]^{\beta}}{\sum\left[\tau_{i j}(t)\right]^{\alpha} \cdot\left[\eta_{i j}\right]^{\beta}},
\end{aligned}
$$

$\Sigma\left[\boldsymbol{\tau}_{i j}(\boldsymbol{t})\right]^{\alpha} \cdot\left[\eta_{i j}\right]^{\beta}$ adalah jumlah nilai $\left[\boldsymbol{\tau}_{i j}(\boldsymbol{t})\right]^{\alpha} \cdot\left[\eta_{\eta_{i j}}\right]^{\beta}$ dari semua node $i$ ke $j$ dan $k$ adalah semut ke- $k$.

Maka:

$$
\begin{aligned}
& \eta_{12}=\frac{1}{c_{12}}=0.1052631579 \\
& p_{12}^{1}(t)=\frac{\left[r_{12}[t]\right]^{\alpha} \cdot\left[\eta_{12}\right]^{\beta}}{\Sigma\left[r_{12}[t]\right]^{1} \cdot\left[\eta_{12}\right]^{\beta}}=\frac{[1]^{1} \cdot[0.1052631579]^{2}}{3.9646431268}=0.0110803324
\end{aligned}
$$


Maka dari itu diperlukan untuk menghitung nilai probabilitas antar node. Selanjutnya berdasakan perhitungan tabulist ke-1, semut ke-1 yang berada di node ke-1 akan bergerak ke node ke-3 berdasarkan probabilitas terbesar dengan nilai $p_{13}^{k}=0.1666666667$.

3. Mencari node berikutnya

Setelah didapatkan node $j$ yaitu 3 maka selanjutnya mencari node selanjutnya dengan mengubah node $j$ menjadi node $i$. Lalu setelah node 3 menjadi node $i$ maka selanjutnya kembali menentukan node $j$ dengan rumus yang sama namun dengan syarat bahwa node $j$ selanjutnya bukan node yang sudah pernah dilalui (misal: node 1 atau 3). Perncarian nodenode selanjutnya dilakukan dengan cara yang sama hingga semua node terlewati. Node-node yang telah dilewati tersebut kemudian disimpan kedalam tabulist sebagai sebuat path.

e. Hitung Probabilitas

Pada tahap ini dilakukan pencarian perolehan probabilitas terbesar dan pheromone terkecil pada path untuk dijadikan rute terbaik. Berikut tahapannya:

1. Menentukan probabilitas path

Menghitung probabilitas sebuah tabulist dengan rumus:

$$
L_{k}=\Sigma P_{i j}^{k_{i j}}(t), \Sigma P_{i j}^{k_{i j}}(t)
$$

yaitu jumlah seluruh probabilitas pada tabulist. Misalkan pada tabulist ke-1 dengan path $1-$ $3-2-5-4-6-7-8-9-11-10-12-13-14$, maka jumlahkan nilai probabilitas 1 ke 3, 3 ke 2, 2 ke 5 dan seterusnya. Berdasarkan perhitungan maka tabulist 1 memperoleh nilai probabilitas $L_{1}=\mathbf{0 . 1 2 4 0 3 1 8 0 3}$. Selanjutnya menghitung tabulist berikutnya dengan cara yang sama.

2. Menghitung perolehan pheromone pada path

Menghitung pheromone sementara dengan rumus:

$$
\Delta \tau_{i j}^{k}=\frac{Q}{L_{k}}
$$

Q adalah iterasi. Contoh dengan menghitung tabulist 1, yaitu:

$$
\Delta \tau_{i j}^{k}=\frac{1}{0.124031803}=8.0624483061
$$

Kemudian hitung pheromone sementara pada tabulist lainnya dengan cara yang sama.

3. Menghitung pheromone global

Pheromone global dihitung dengan menggunakan rumus $\Delta \tau_{i j}=\sum_{k=1}^{m} \Delta \tau_{i j}^{k}$, yaitu menjumlahkan pheromone sementara pada semua tabulist. Maka akan dihasilkan pheromone global pada perhitungan ini sebesar 134.9274224269.

4. Menghitung perolehan pheromone pada tiap tabulist

Tahap ini dilakukan dengan dengan persamaan $\Delta \boldsymbol{\tau}_{i j}=\Delta \tau_{i j}+\Delta \tau_{i j}^{k}$, yaitu menambahkan pheromone sementara pada masing-masing tabulist dengan pheromone global. Contoh pada tabulist 1:

$\Delta \tau_{i j}=134.9274224269+8.0624483061=142.989870733$.

Maka berdasarkan perhitungan dari tahapan 1 sampai 4 perhitungan algoritme ACO, diperoleh hasil seperti pada Tabel 4 . 
Tabel 4. Hasil perhitungan algoritme ACO pada objek wisata

\begin{tabular}{|c|c|c|c|}
\hline $\begin{array}{l}\text { Tab } \\
\text { ulist }\end{array}$ & Path & $\begin{array}{l}\text { Nilai } \\
\text { Probabilitas }\end{array}$ & $\begin{array}{l}\text { Perolehan } \\
\text { Pheromone }\end{array}$ \\
\hline 1 & $\begin{array}{l}1-3-2-5-4-6-7-8-9-11-10 \\
-12-13-14\end{array}$ & 0.124031803 & 142.989870733 \\
\hline 2 & $\begin{array}{l}2-3-1-7-9-8-10-11-5-6-4 \\
-12-13-14\end{array}$ & 0.113611837 & 143.7293221797 \\
\hline 3 & $\begin{array}{l}3-2-1-8-11-10-9-7-12-13 \\
-14-4-5-6\end{array}$ & 0.111949492 & 143.8600221389 \\
\hline 4 & $\begin{array}{l}4-3-2-1-9-10-11-8-7-12 \\
-13-14-6-5\end{array}$ & 0.100486273 & 144.879030444 \\
\hline 5 & $\begin{array}{l}5-2-3-1-7-8-11-9-10-12 \\
-13-14-4-6\end{array}$ & 0.116981086 & 143.4758128906 \\
\hline 6 & $\begin{array}{l}6-2-3-1-7-8-11-9-10-12 \\
-13-14-4-5\end{array}$ & 0.116981086 & 143.4758128906 \\
\hline 7 & $\begin{array}{l}7-1-3-2-5-4-6-8-9-11-10 \\
-12-13-14\end{array}$ & 0.124031803 & 142.989870733 \\
\hline 8 & $\begin{array}{l}8-10-9-11-1-3-2-5-4-6-7 \\
-12-13-14\end{array}$ & 0.111849988 & 143.8679687594 \\
\hline 9 & $\begin{array}{l}9-7-1-3-2-5-4-6-8-10-11 \\
-12-13-14\end{array}$ & 0.092141916 & $\begin{array}{l}1145.780246455 \\
4\end{array}$ \\
\hline 10 & $\begin{array}{l}10-9-8-11-12-13-14-7-1-3 \\
-2-5-4-6\end{array}$ & 0.107601829 & 144.2209447517 \\
\hline 11 & $\begin{array}{l}11-10-9-8-12-13-14-7-1-3 \\
-2-5-4-6\end{array}$ & 0.11995662 & 143.2637693496 \\
\hline 12 & $\begin{array}{l}12-1-3-2-5-4-6-7 \\
-8-9-11-10-13-14\end{array}$ & 0.103331972 & 144.6049692756 \\
\hline 13 & $\begin{array}{l}13-14-12-9-8-11-10 \\
-1-7-3-5-4-6-2\end{array}$ & 0.06835129 & 149.557330591 \\
\hline 14 & $\begin{array}{l}14-13-12-11-10-9-8 \\
-7-1-2-5-3-4-6\end{array}$ & 0.081373965 & 147.216365211 \\
\hline
\end{tabular}

5. Lakukan Iterasi

Jika akan dilakukan iterasi maka lakukan tahap 7 terlebih dahulu, jika tidak maka tahap 6 dan 7 dapat dilewati.

6. Update pheromone

Update pheromone dilakukan dengan persamaan sebagai berikut:

$$
\begin{aligned}
\boldsymbol{\tau}_{\text {ij }}(\boldsymbol{t}+\boldsymbol{n}) & =\boldsymbol{\rho} \boldsymbol{\tau}_{\text {ij }}(\boldsymbol{t})+\Delta \boldsymbol{\tau}_{\text {if }} \\
& =0.5 \times 1+134.9274224269=135.4274224269
\end{aligned}
$$

7. Cetak hasil

Hasil Rute Terbaik diambil berdasarkan probabilitas terbesar dan pheromone terkecil yaitu pada tabulist 1 dan 7 . 


\subsubsection{Analisis Sistem}

a. System Activities (Use Case Diagram)

Use case pada sistem terdiri dari satu aktor yaitu pengguna sebagai orang yang menggunakan aplikasi serta enam use case. Secara lebih rinci dapat dilihat pada Gambar 2.

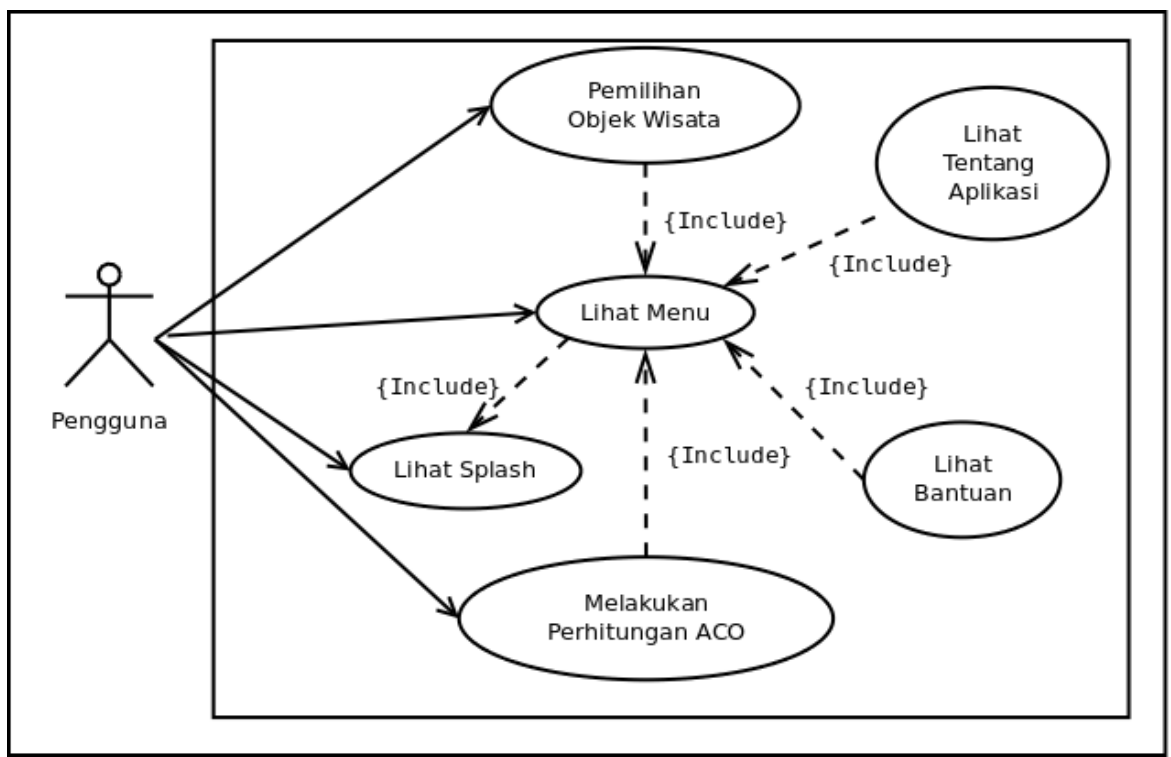

Gambar 2. Usecase Diagram

b. Class Diagram (Class Definition, Class Relation)

1. Class Diagram

Aplikasi Pemilihan Objek Wisata memiliki 6 class yang terdiri dari class Splash, Main, AntSystem, PemilihanWisata dan Help seperti pada Gambar 3.

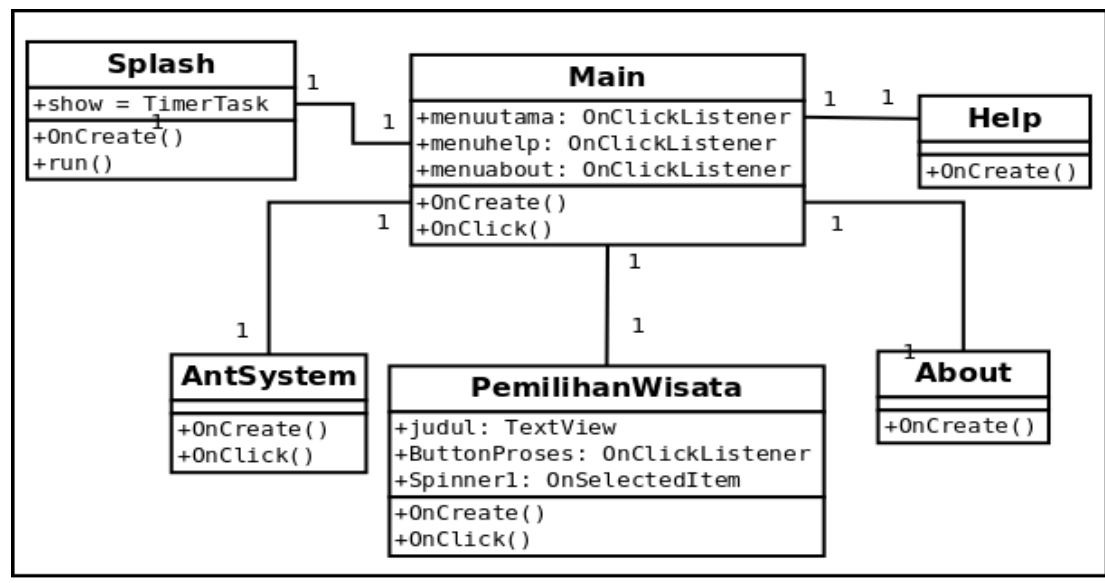

Gambar 3. Class Diagram

2. Class Definition

Berdasarkan Class Diagram pada Gambar 3, maka deskripsi setiap class dapat dilihat pada Tabel 5. 
Tabel 5. Deskripsi class diagram

\begin{tabular}{lll}
\hline No & Nama Class & Deskripsi \\
\hline 1 & Splash & Merupakan kelas untuk menampilkan splash \\
2 & Main & Merupakan kelas untuk menampilkan menu aplikasi \\
3 & PemilihanWisata & Merupakan kelas untuk melakukan pemilihan objek wisata \\
4 & AntSystem & $\begin{array}{l}\text { Merupakan kelas untuk melakukan perhitungan algoritme ACO } \\
\text { dalam menentukan rute terbaik }\end{array}$ \\
5 & Tentang & Merupakan kelas untuk menampilkan halaman tentang aplikasi \\
6 & Bantuan & Merupakan kelas untuk menampilkan halaman bantuan \\
\hline
\end{tabular}

c. Object Interaction (Sequence Diagram)

Diagram Sequence aplikasi Pemilihan Objek Wisata dapat dilihat pada gambar 4.

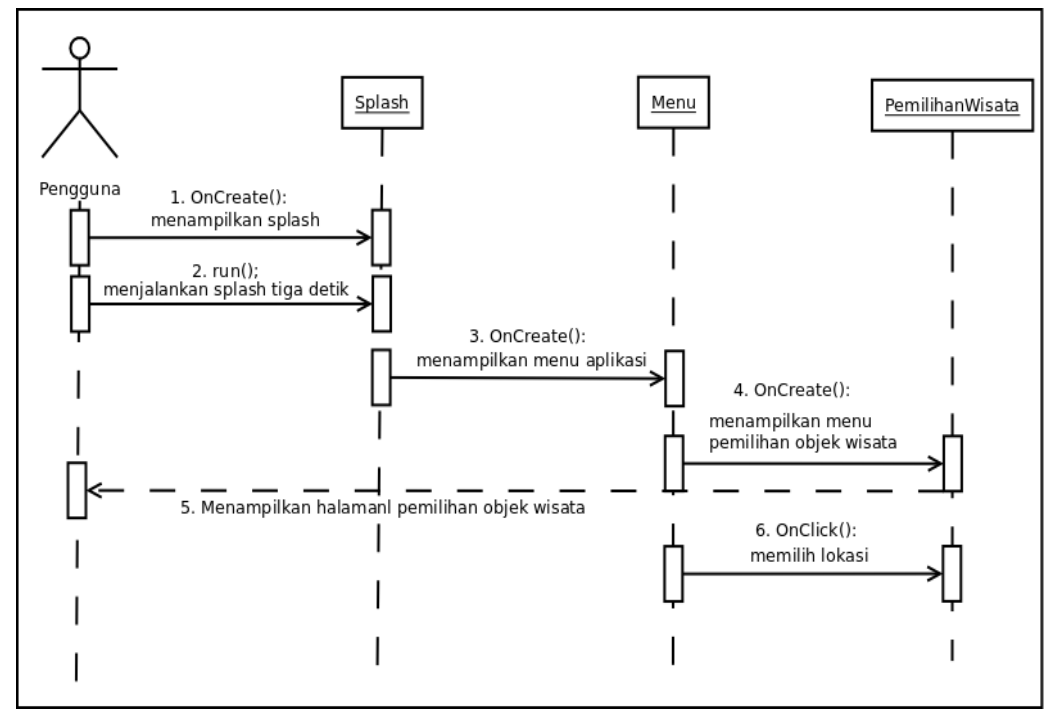

Gambar 4. Sequence Diargam Pemilihan Objek Wisata

\subsection{Design Phase}

Pada tahapan Design Phase menggunakan Object Oriented Design (OOD) berupa desain proses dan desain antarmuka aplikasi. Dimana desain proses menggambarkan proses aplikasi secara keseluruhan, dimulai dari tampilan splash saat aplikasi pertama dibuka, pemilihan menu hingga keluar dari aplikasi. Dapat dilihat pada Gambar 5 desain proses aplikasi Pemilihan Objek Wisata.

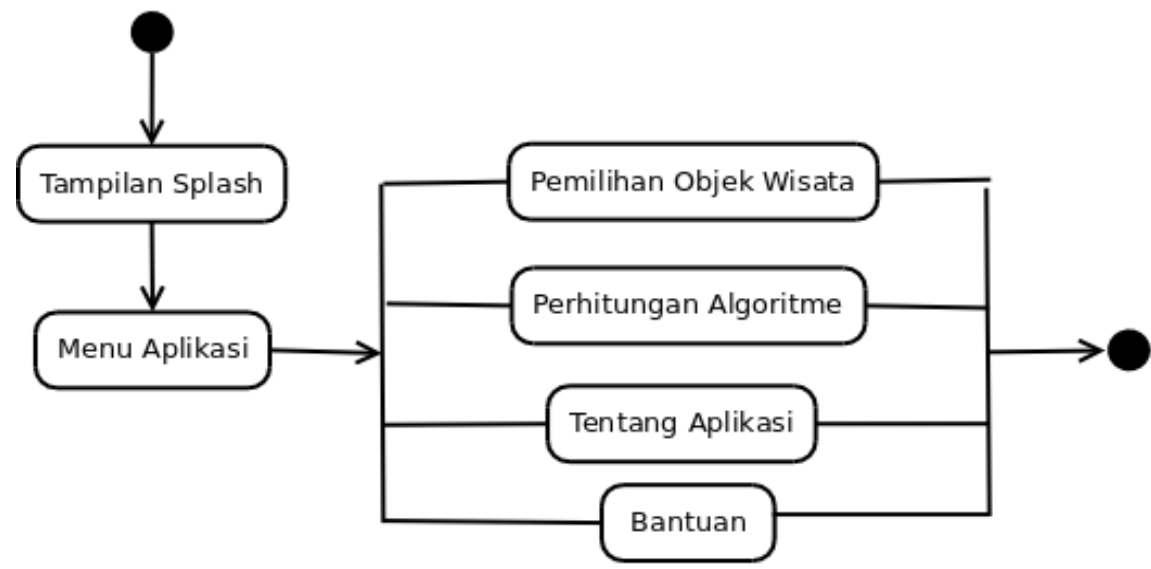

Gambar 5. Desain Proses Aplikasi Pemilihan Objek Wisata

Berdasarkan desain proses pada Gambar 5, desain antarmuka aplikasi Pemilihan Objek Wisata pada menu Pemilihan Objek Wisata dapat dilihat pada Gambar 6. 


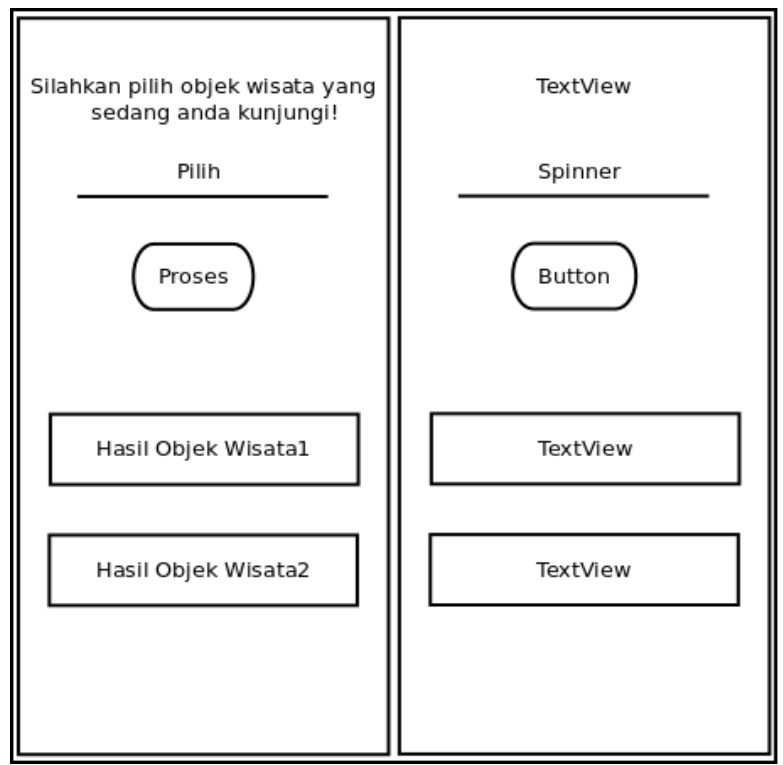

\section{Gambar 6. Desain Antarmuka Pemilihan Objek Wisata}

\subsection{Implementation Phase}

Tahap implementasi sistem merupakan tahap di mana sistem siap untuk dioperasikan dengan tujuan untuk menguji coba sistem yang telah dibuat.

a. Instalasi Sistem

Instalasi sistem terdiri dari instalasi perangkat lunak dan perangkat keras. Perangkat lunak yang dibutuhkan agar dapat menjalankan aplikasi ini adalah sistem operasi minimum Android Gingerbread 2.3.1. Agar aplikasi dapat berjalan dengan baik dibutuhkan perangkat keras smartphone/tablet dengan minimal spesifikasi sebagai berikut:

1. Processor minimum $1000 \mathrm{Mhz}$

2. RAM dengan kapasitas minimum $1 \mathrm{~Gb}$

3. Internal Storage dengan kapasitas minimum $1 \mathrm{~Gb}$

b. Fitur Aplikasi

Aplikasi pemilihan objek wisata Karawang ini memiliki fitur Pemilihan Wisata, Perhitungan Algorutme ACO, Tentang Aplikasi dan Bantuan. Berikut adalah tampilan fitur Pemilihan Objek Wisata pada Gambar 7 dan Perhitungan Algoritme ACO pada Gambar 8.

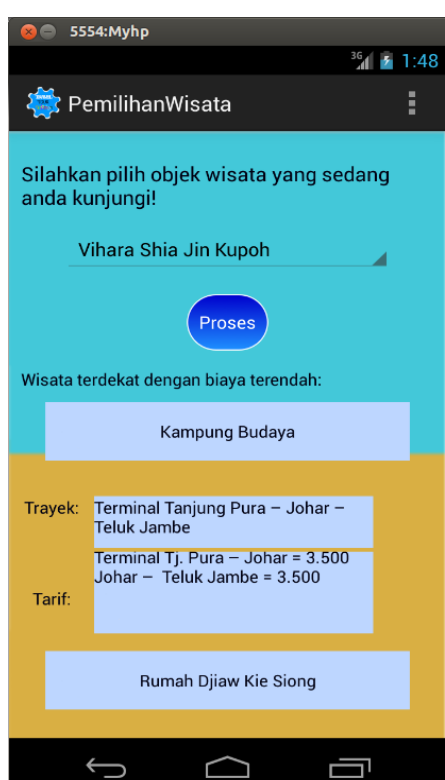

Gambar 7. Menu Pemilihan Objek Wisata

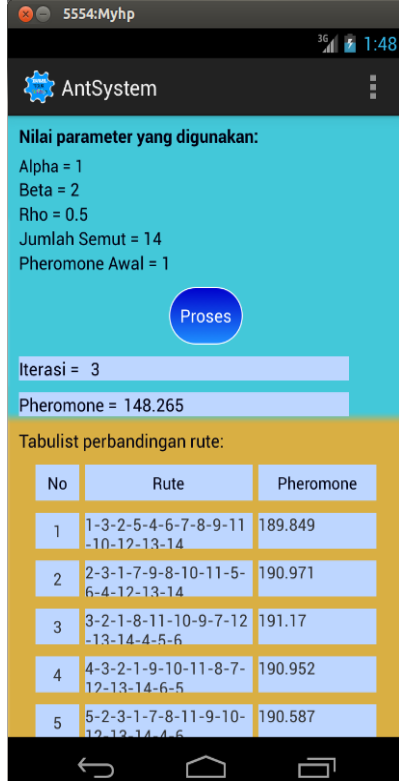

Gambar 8. Perhitungan Algoritme ACO 


\section{KESIMPULAN}

Berdasarkan tahap-tahap penelitian yang telah dilakukan maka dapat disimpulkan :

a. Dalam menentukan nilai optimal menggunakan algoritme ACO dengan variabel biaya dapat dilakukan dengan menentukan probabilitas terbesar dan nilai pheromone terkecil berdasarkan 8 tahapan perhitungan algoritme ACO, yakni identifikasi $d_{i \tilde{i}}$, inisialisasi parameter awal, menentukan jumlah semut, membuat tabulist, menghitung probabilitas dan pheromone, lakukan iterasi, kemudian lakukan update pheromone dan cetak hasil rute terbaik.

b. Pembangunan sistem dilakukan dengan melakukan beberapa tahapan metode SDLC waterfall dari projet planning phase, analysis phase, design phase dan implementation phase, yaitu pada setiap tahapan menjelaskan perkembangan pembangunan sistem.

\section{DAFTAR PUSTAKA}

[1] Fatkhurrozi, Bagus., dan Setyowati, Ika. 2015. "P'encarian Rute Terpendek Objek Wisata di Magelang Mengunakan Ant Colony Optimization (ACO)." Prosiding SENATEK. 205-212.

[2] Ramuna, Maretta., dan Mahmudy, Wayan. 2015. "Optimasi persediaan barang dalam produksi jilbab menggunakan alroritma genetika." DORO: Repository Jurnal Mahasiswa PTIIK Universitas Brawijaya. Volume, 5. No. 14.

[3] Kurniawan, Defri., dan Supriyanto, Catur. 2013. "Optimasi Algoritma Support Vector Machine (SVM) Menggunakan ADABOOST untuk Penilaian Risiko Kredit." Jurnal Teknologi Informasi. Volume, 9. Nomor, 1.

[4] Paryanti. 2009. "Optimasi Strategi Algoritma Greedy untuk Menyelesaikan Permasalahan Knapsack 0-1.” SemnasIF. A-101-110.

[5] Dorigo, Marco., and Gambardella, LM.1996. "Ant Colonies for the traveling salesman problem." Université Libre de Bruxelles.

[6] Joni, IDMAB., dan Nurcahyawati, Vivine. 2012. "Penentuan Jarak Tetpendek pada Jalur Distribusi Barang di Pulau Jawa dengan Menggunakan Algoritma Genetika." JANAPATI. Volume, 1. Nomor, 3. 244-258.

[7] Togatorop, Disbun. 2014. "Perancangan Aplikasi Pencarian Jalur Terpendek dengan Algoritma TABU SEARCH.” Pelita Informatika Budi Darma. Volume, 7. Nomor, 1. 49-54.

[8] Anadayani, Sri., dan Perwitasari, EW. 2014. "Penentuan Rute Terpendek Pengambilan Sampah di Kota Merauke Menggunakan Algoritma Dijkstra." SEMANTIKA . ISBN: 979-26-0276-3. 164-170.

[9] Satzinger, John, w., et al. 2010. Systems Analysis and Design in a Changing World, Fifth Edition. Boston: Course Technology.

[10] Suyanto. 2010. Algoritma Optimsi Deterministik dan Probabilistik. Yogyakarta: Graha Ilmu 